\title{
A short-term study on the phytoplanktonic and epilithic algae of Arda River (Edirne, Turkey)
}

\section{Arda Nehri (Edirne, Türkiye) fitoplanktonik ve epilitik algleri üzerine kısa dönem bir çalışma}

\author{
Burak Öterler \\ Trakya University, Faculty of Sciences, Biology Department, 22030 Edirne, Turkey \\ burakoterler@trakya.edu.tr
}

How to cite this paper:

Öterler, B. (2016). A short-term study on the phytoplanktonic and epilithic algae of Arda River (Edirne, Turkey). Ege Journal of Fisheries and Aquatic Sciences, 33(3): 299-306. doi: 10.12714/egejfas.2016.33.3.16

\begin{abstract}
Arda River, being one of the biggest tributaries of Meriç River passes through Bulgaria, Greece and merges to the Meriç River in Edirne provincial borders. Only 500 meter of the river is inside Turkey borders and sampling station selected this area. In this study, the species structure and quantitative development of the summer phytoplankton and epilithic algae were examined in 2011. A total of 57 species was found, belonging to 4 divisions: Bacillariophyta 31 taxa, Chlorophyta 18 taxa, Euglenophyta 5 taxa and Cyanophyta 3 taxa. The most common taxa in the phytoplankton were Pediastrum sp., Cyclotella meneghiniana and Cymatopleura sp. while Cymatopleura sp., Fragilaria sp. and Pinnularia sp. were the most common in the epilithic. Canonical correspondance analyses have been applied to clarify relationships between environmental variables and planktonic and benthic algae. The results of the CCA showed differing relationships between the environmental variables and the phytoplanktonic and epilitic taxa.
\end{abstract}

Keywords: Phytoplankton, epilithic algae, Turkey, Arda River

Öz: Tunca ve Ergene Nehirleriyle beraber Meriç Nehri'nin en büyük kollarından biri olan Arda Nehri, Bulgaristan'da doğar ve Edirne il merkezi sınırları içinde Meriç Nehri ile birleşir. Nehrin Türkiye sınırları içinde kalan kısmı ise sadece 500 metredir ve örnekleme istasyonu bu bölgeden seçilmiştir. Bu çalışma ile Arda Nehri'nin yaz aylarındaki planktonik ve bentik alg türlerinin kompoziyonunu ve nicel gelişimi belirlemek amacıyla 2011 yılında yapılmıştır. Çalışma sonunda Bacillariophyta'ya ait 31 taxa, Chlorophyta'ya ait 18 taxa, Euglenophyta'ya ait 5 taxa ve Cyanophyta'ya ait 3 taxa olmak üzere 4 divisioya ait toplam 57 tür tespit edilmiştir. Çalışma sonucunda planktonik olarak Pediastrum sp., Cyclotella meneghiniana ve Cymatopleura sp., epilitik olarak ise Cymatopleura sp., Fragilaria sp. ve Pinnularia sp. türleri nehrin hakim organizmaları olmuştur. Canonical Correspondance analizi sonuçlarına göre çevresel değişkenler ile planktonik ve bentik algler arasındaki ilişkiler tespit edilmişlerdir.

Anahtar kelimeler: Fitoplankton, epilitik algler, Türkiye, Arda Nehri

\section{INTRODUCTION}

Traditionally, phytoplankton and benthic algae are analysed and discussed separately, with different relationships between these and the environmental variables assumed, due to their different ecology. The methods adopted for the analysis of the two algal communities are different, being based mainly on total biovolume for phytoplankton and on number of individuals for benthic algae (Tolotti, 2001). Algal communities of river systems consist not only of suspended algae, but also a diverse benthic assemblage of macrophytic forms, smaller epilithic species, epiphytes, and sediment-dwelling forms (Reynolds, 1996). The phytoplankton and epilithic algae (attached to stones) plays a major role in gross production in the aquatic ecosystems and are a food resource of invertebrates in particular in aquatic ecosystems. In aquatic environments, algae are usually divided into different groupsphytoplankton, metaphyton and periphyton- according to their physical distribution (Wehr and Descy, 1998). The epilithic algae constitute the major part of the perinphyton and their species composition usually differs strongly from that of the phytoplankton since it is dominated by species capable of attachment to the substrate. Like the phytoplankton, the epilithic community exhibits pronounced seasonality in response to changes in nutrients and temperature (Wehr and Sheath, 2003).

The principal aim of the present study is to continue, in a more comprehensive effort, the study of the species diversity, structure, distribution and quantitative development of the 
phytoplankton and epilithic algae in Arda River and by this means to start a foundation for water-quality monitoring. In addition, no study has been done on algal population of the Greece and Turkey parts of the river. Although there exist many studies on rivers in Anatolian part of Turkey, European part is quite short of similar studies. Therefore, we think that the present study will contribute greatly to Turkish freshwater algal database.

\section{MATERIAL AND METHOD}

\section{Site description}

Arda River, being one of the biggest tributaries of Meriç River with Tunca and Ergene Rivers, rises from the Rodop Mountains in southern Bulgaria, passes through northeast of Greece and merges to the Meriç River in Edirne provincial borders. Arda River is $290 \mathrm{~km}$ long, of which $241 \mathrm{~km}$ section is inside Bulgaria and $49 \mathrm{~km}$ section is in Greece borders (Belkinova et al., 2007; Algın, 2013). Only 500 meter of the river is inside Turkey borders. In the study area was measured the width $40 \mathrm{~m}$ and the maximum depth $175 \mathrm{~cm}$. Three dam lakes have been builted along the river, one of which is Kurdzhali Reservoir as the $2^{\text {nd }}$ biggest dam lake in Bulgaria, and water from these dams is used for drinking water supply, power generation and irrigation (Belkinova et al., 2007).

\section{Collected algae, count and biovolume calculated}

Planktonic algal samples were collected from the surface layer in Glass bottles (of 2 liter) and epilithic samples were collected stone and pebble from the bottom of, Arda River thrice on 27 May 2011, 20 June 2011 and 24 July 2011. The location of the sampling station was shown in Figure 1.

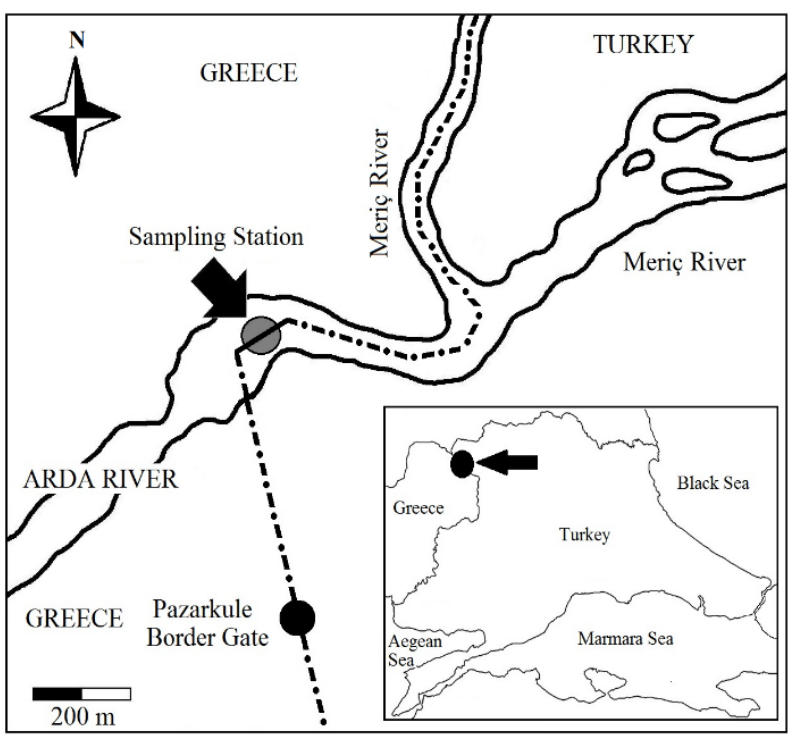

Figure 1. The location of Arda River and the sampling station at the Greece-Turkey Border
Sampled phytoplankton specimens were identified by investigation of temporary preparations. For this purpose, water samples were filtered from Whatman GF/A paper with the help of a water trompe and dissolved in $10 \%$ glycerol. An Uthermol counting chamber was used to calculate the organism number per liter. 25, 50 and $100 \mathrm{~mL}$ of sub-samples of water samples were prepared and settled according to Utermöhl (1958) and then organism countings and calculations were made. Algae species were identified with a binocular microscope. Chlorophyll a analyses (ethanol was used as the solvent) have been carried out according to Nusch (1980).

In order to obtain epilithic samples, 10 stones of palm size with relatively smooth upper surface were collected and the algae on the upper surfaces of these stones were scraped with a brush in a plastic container containing $300 \mathrm{~mL}$ distilled water. The algae rinsed with water was transferred to proper volume bottles filled with Lugol solution containing $10 \%$ glycerol added as a fixative and the bottles were taken to the laboratory with their lids tightly closed. The sampled surfaces of the collected stones were measured using a simple ruler and the surface area of the scratched regions was calculated. For organism countings and calculations, 1,5 and $10 \mathrm{~mL}$ of sub-samples of water samples were prepared and settled according to Utermöhl (1958).

Permanent slides were prepared for identifications of diatoms from the same sample after boiling in a 1:1 mixture of concentrated $\mathrm{H}_{2} \mathrm{SO}_{4}$ and $\mathrm{HNO}_{3}$. Slurries were rinsed several times in distilled water until neutral $\mathrm{pH}$ was reached. Slurries were dried overnight on coverslips and permanent slides for identification of diatoms were prepared using Naphrax high refractive index medium (Round, 1953). Phytoplankton and epilitic algal biovolume was estimated from abundance data and measurements of specific cell volume by approximating geometric shapes of the cells (Hillebrand et al., 1999; Sun and Liu, 2003). Dimensions of the least 25 individuals were measured, and the mean volume of each taxon was multiplied by the corresponding concentration to derive species-specific standing-crop volumes. Identifications were carried out at 1000x magnification under immersion oil and identification of taxa was done with the help of related literature (Husted, 1930; Pestalozzi, 1982; Round, 1953; Cleve-Euler, 1952; Patrick and Reimer, 1966; Prescott, 1973; Komarek and Fott, 1983; Krammer and Lange-Bertalot, 1991a; 1991b; 1999). Finally, all species were checked in algaebase (Guiry et al., 2010).

\section{Water analyses}

A Ruttner water sampler was used to obtain water samples below the surface of the water body in order to determine some physico-chemical properties of the river. Water temperature, $\mathrm{pH}$, dissolved oxygen and specific conductivity values were measured on site using field type equipments (Lovibond Sensodirenct model portable probes), $\mathrm{NO}_{3}-\mathrm{N}, \mathrm{NO}_{2}-\mathrm{N}$, Soluble Reactive Phosphorus (SRP) and Total suspended solids (TSS) were measured in laboratory in accordance with APHA-AWWAWPCF methods (APHA, 2012). The quality level of the water 
was determined according to Turkish Surface Water Quality Managament Framework (YSKYY, 2015).

\section{Statistical analyses}

Multivariate analyses were used to identify environmental parameters that were most strongly associated with each other and to define associations between environmental factors and algal species.

The Canonical Correspondence Analysis (CCA) (ter Braak, 1986) was performed with XLSTAT-ADA statistical package in order to determine the relative importance of environmental variables on algal species (Addinsoft, 2015).

\section{RESULTS AND DISCUSSION}

The 46 phytoplanktonic taxa in the river was represented with Bacillariophyta (21 taxa), Chlorophyta (18 taxa), Euglenophyta (5 taxa and Cyanophyta (2 taxa) and the 33 epilithic taxa in the river was represented with Bacillariophyta (23 taxa), Chlorophyta (9 taxa) and Cyanophyta (1 taxon) (Table 1).

Table 1. Algal composition of the Arda River May, June and July 2011

\begin{tabular}{llllllll}
\hline & \multicolumn{3}{c}{ PLANKTONIC } & & \multicolumn{3}{c}{ EPILITHIC } \\
\cline { 2 - 6 } & May & June & July & May & June & July \\
\hline
\end{tabular}

\section{CYANOPHYTA}

Anabaena flosaquae West 1907

Microcystis aeruginosa (Kütz.) Kütz. 1846

Oscillatoria limosa Agardh 1892

\section{EUGLENOPHYTA}

Euglena acus (Müller) Ehren.

Euglena polymorpha Dangeard

Phacus longicauda (Ehren.) Dujardin

Trachelomonas hispida (Perty) Stein

Trachelomonas volvocina (Ehren.) Ehren.

\section{CHLOROPHYTA}

Actinastrum hantzschii Lagerheim

Acutodesmus acuminatus (Lag.) Tsarenko

Chlorella sp.

Coelastrum astroideum De Notaris

Crucigenia tetrapedia (Kirch.) Kuntze

Desmodesmus spinosus (Chod.) Hegewald

Dictyosphaerium pulchellum Wood

Lagerheimia wratislaviensis Schröder

Monactinus simplex (Meyen) Corda

Monoraphidium contortum (Thu.) Kom.-Leg.

Oocystis sp.

Pediastrum boryanum (Turp.) Meneg.

Pediastrum duplex Meyen

Scenedesmus ecornis (Ehr.) Chodat

Scenedesmus communis Hegewald

Tetraedron minimum (Braun) Hans.

Tetradesmus obliquus (Turp.) Wynne

Tetrastrum staurogeniaeforme (Schr.) Lemm.

\section{BACILLARIOPHYTA}

Amphora ovalis Kütz.

Asterionella formosa Hassall

Aulacoseira granulata (Ehr.) Simon. 


\author{
Cocconeis placentula Ehrenberg \\ Cyclotella meneghiniana Kütz. \\ Cymatopleura elliptica (Bréb.) Smith \\ Cymatopleura solea (Bréb.) Smith \\ Cymbella cymbiformis Agardh \\ Cymbella tumida (Bréb.) van Heurck \\ Diatoma vulgare Bory \\ Fragilaria acus Kütz. L-Bertalot \\ Fragilaria crotonensis Kitton \\ Fragilaria ulna (Nitz.) L-Bertalot \\ Fragilaria virescens Ralfs \\ Gomphonema acuminatum Ehrenberg \\ Gomphonema olivaceum (Horn.) Bréb. \\ Hantzschia amphioxys (Ehren.) Grun. \\ Melosira varians Agardh \\ Navicula capitata Ehren. \\ Navicula radiosa Kützing \\ Navicula sp. \\ Navicula viridula (Kütz.) Kütz. \\ Nitzschia acicularis (Kütz.) Smith \\ Nitzschia balcanica Hustedt \\ Nitzschia palea (Kütz.) Smith \\ Nitzschia sigmoidea (Nitzsch) Smith \\ Nitzschia sp. \\ Pinnularia brebissonii (Kütz.) Raben. \\ Pinnularia viridis (Nitzsch) Ehren. \\ Surirella elegans Ehren. \\ Tabellaria fenestrata (Lyngbye) Kütz.
}

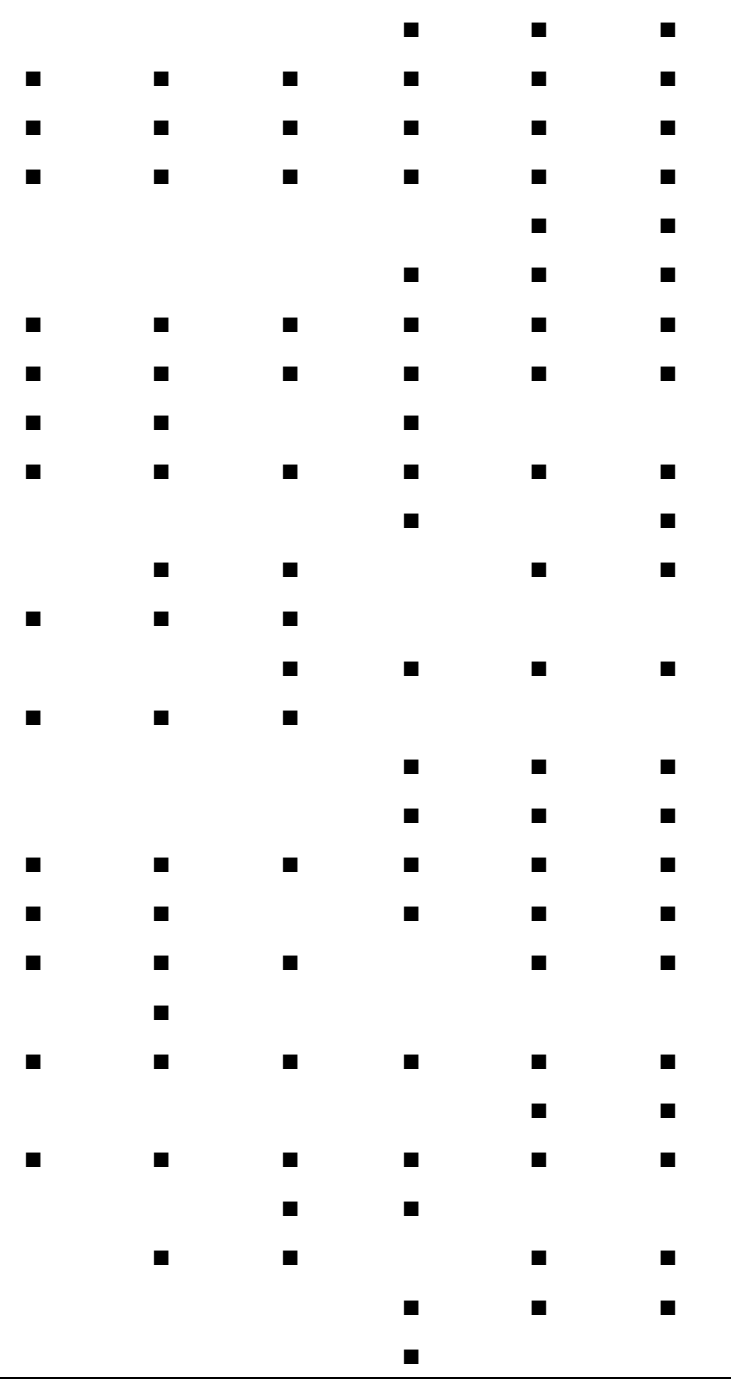

In May, total of 32 species were determined in plankton. Although there was no significant dominance in calculated relative biovolumes of species defined in plankton (2.05$8.12 \%)$, Euglena polymorpha (8.12\%), Pediastrum duplex (7.54\%), Cyclotella meneghiniana (5.96\%) and Tetradesmus obliguus (4.85\%) species were determined as organisms having the highest relative biovolumes in May. The epilithic fauna in May was found to be represented with 28 species. 21.4 $\%$ of the biovolume in the benthic region was Anabaena flosaquae, $16.44 \%$ was Cyclotella meneghiniana, $14.15 \%$ was Cymatopleura spp. $10.92 \%$ was Hantzschia amphioxys and $9.37 \%$ was Pinnularia viridis in May, all which were the dominant organisms of the study field.

In June, 41 species were determined as planktonic. In river plankton from diatoms, Cyclotella meneghiniana (18.72\%), Melosira varians (14.48\%), Fragilaria crotonensis (12.65\%) and Cymatopleura elliptica (12.18\%), and from green algae Pediastrum (18.22\%) species increased their relative biovolumes in this month. Increase of Pediastrum species and
Monactinus simplex in the summer months in Bulgaria part of the river has been determined by Belkinova et. al (2007). The epilithic algae in June was represented with 29 species and after the counts and the calculations, Fragilaria spp. (highest) (16.25\%), Cymatopleura spp. (14.82\%), Cocconeis placentula $(12.41 \%)$, Pinnularia viridis (10.21\%) and Amphora ovalis $(7.55 \%)$ were determined to have the highest relative biovolumes, respectively. Similar species were also determined by Belkinova et al. (2007).

In July, 40 phytoplanktonic species were determined. Especially with the increase of Pediastrum duplex, Pediastrum species (and Monactinus simplex) became the dominant organism with $24.15 \%$. After Pediastrum, from the diatoms, Cyclotella meneghiniana (14.25\%), Cymatopleura spp. $(13.17 \%)$ and Fragilaria spp. (especially Fragilaria crotonensis $8.65 \%$ ) were the highest ones, respectively. For the epilithic algae, 31 species were determined as it was in June, and after the counts and the calculations, Cymatopleura spp. (highest) (16.85\%), Fragilaria spp. (15.48\%), Pinnularia viridis (13.18\%) 
and Cocconeis placentula (9.25\%) were found to have the highest relative biovolumes, respectively.

Bacillariophyta was the dominant group of the river in phytoplankton with (606200 ind. $\left.\mathrm{I}^{-1}\right)$ followed by Chlorophyta (224600 ind. $\mathrm{I}^{-1}$ ), Cyanophyta (49400 ind. $\mathrm{I}^{-1}$ ) and Euglenophyta (35800 ind. I-1) $^{-1}$. Bacillariophyta was also dominant in the benthic zone with $\left(3675\right.$ ind $\left./ \mathrm{cm}^{2}\right)$ followed by Chlorophyta and Cyanophyta with $1089 \mathrm{ind} / \mathrm{cm}^{2}$ and $512 \mathrm{ind} / \mathrm{cm}^{2}$, respectively. The relative biovolume values of the sampled phytoplanktonic taxa, and the relative biovolume values of the sampled epilithic taxa were given in Figures 2 and Figure 3 .

In May, total of 32 species were determined in plankton. Although there was no significant dominance in calculated relative biovolumes of species defined in plankton (2.05$8.12 \%)$, Euglena polymorpha (8.12\%), Pediastrum duplex (7.54\%), Cyclotella meneghiniana $(5.96 \%)$ and Tetradesmus obliguus $(4.85 \%)$ species were determined as organisms having the highest relative biovolumes in May. The epilithic fauna in May was found to be represented with 28 species. 21.4 $\%$ of the biovolume in the benthic region was Anabaena flosaquae, $16.44 \%$ was Cyclotella meneghiniana, $14.15 \%$ was Cymatopleura spp. $10.92 \%$ was Hantzschia amphioxys and $9.37 \%$ was Pinnularia viridis in May, all which were the dominant organisms of the study field.

In June, 41 species were determined as planktonic. In river plankton from diatoms, Cyclotella meneghiniana (18.72\%), Melosira varians (14.48\%), Fragilaria crotonensis (12.65\%) and Cymatopleura elliptica (12.18\%), and from green algae Pediastrum (18.22\%) species increased their relative biovolumes in this month. Increase of Pediastrum species and Monactinus simplex in the summer months in Bulgaria part of the river has been determined by Belkinova et. al (2007). The epilithic algae in June was represented with 29 species and after the counts and the calculations, Fragilaria spp. (highest) (16.25\%), Cymatopleura spp. (14.82\%), Cocconeis placentula (12.41\%), Pinnularia viridis $(10.21 \%)$ and Amphora ovalis $(7.55 \%)$ were determined to have the highest relative biovolumes, respectively. Similar species were also determined by Belkinova et al. (2007).

In July, 40 phytoplanktonic species were determined. Especially with the increase of Pediastrum duplex, Pediastrum species (and Monactinus simplex) became the dominant organism with $24.15 \%$. After Pediastrum, from the diatoms, Cyclotella meneghiniana (14.25\%), Cymatopleura spp. $(13.17 \%)$ and Fragilaria spp. (especially Fragilaria crotonensis $8.65 \%$ ) were the highest ones, respectively. For the epilithic algae, 31 species were determined as it was in June, and after the counts and the calculations, Cymatopleura spp. (highest) (16.85\%), Fragilaria spp. (15.48\%), Pinnularia viridis (13.18\%) and Cocconeis placentula $(9.25 \%)$ were found to have the highest relative biovolumes, respectively.

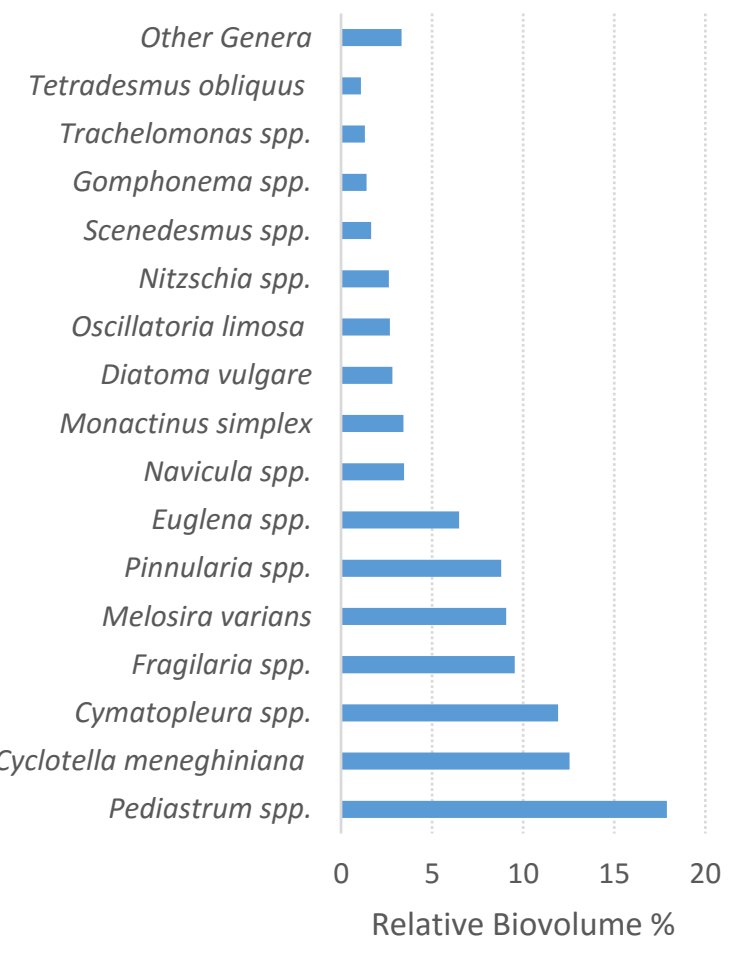

Figure 2. The relative biovolume values of phytoplanktonic taxa in Arda River

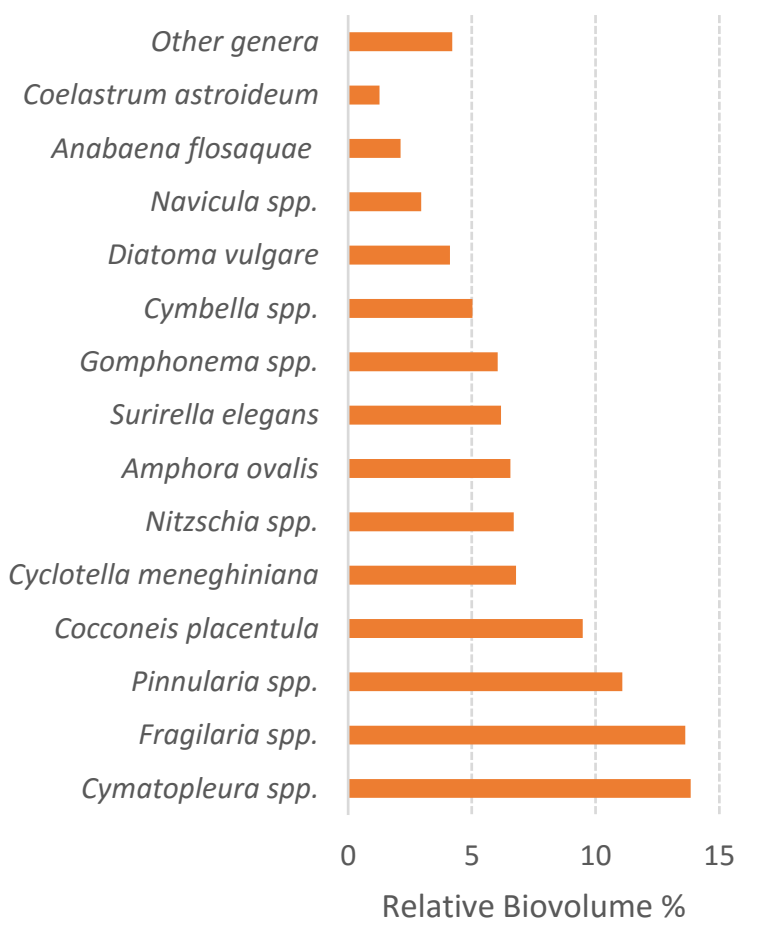

Figure 3. The relative biovolume values of epilithic taxa in Arda River 
Bacillariophyta was the dominant group of the river in

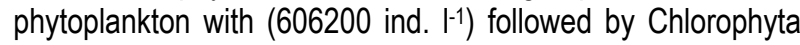
(224600 ind. $\mathrm{I}^{-1}$ ), Cyanophyta (49400 ind. $\mathrm{I}^{-1}$ ) and Euglenophyta (35800 ind. I $^{-1}$ ). Bacillariophyta was also dominant in the benthic zone with $\left(3675\right.$ ind $\left./ \mathrm{cm}^{2}\right)$ followed by Chlorophyta and Cyanophyta with 1089 ind $/ \mathrm{cm}^{2}$ and 512 ind $/ \mathrm{cm}^{2}$, respectively. The relative biovolume values of the sampled phytoplanktonic taxa, and the relative biovolume values of the sampled epilithic taxa were given in Figures 2 and Figure 3.

In terms of temperature, $\mathrm{pH}$, SRP and TSS values, Arda River was confirmed to be first class water quality according to Surface Water Quality Management Framework Criteria
(YSKYY, 2015). When the classification was based on dissolved oxygen and nitrate nitrogen, the river was placed in second class. All pH data in Arda River was measured between 6.5-9.5 limit value which has been stated in TS 266 and European Communities drinking water directives (TS, 266, 2005; EC, 2007). Conductivity values in Arda River were measured as 1220,1325 and $1350 \mathrm{mho} \mathrm{cm}^{-1}$. The conductivity data determined in the river is lower than the limit values stated in the TS 266 and EC drinking water directives $\left(2500 \mathrm{mho} \mathrm{cm}^{-1}\right)$ (TS, 266; EC, 2007). The mean values of physico-chemical analysis of the water samples were given in Table 2 .

Table 2. Physical and water quality characteristics of the sampling dates of the station on Arda River

\begin{tabular}{lccc}
\hline & May 2011 & June 2011 & July 2011 \\
\hline Temperature $\left({ }^{\circ} \mathrm{C}\right)$ & 14 & 22 & 26 \\
Dissolved $\mathrm{O}_{2}\left(\mathrm{mg} \mathrm{l}^{-1}\right)$ & 6.3 & 4.5 & 5.1 \\
Conductivity $\left(\mathrm{mho} \mathrm{cm}^{-1}\right)$ & 1220 & 1350 & 1325 \\
$\mathrm{pH}$ & 8.65 & 8.51 & 8.92 \\
$\mathrm{~N}-\mathrm{NO}_{2}^{-}\left(\mathrm{mg} \mathrm{l}^{-1}\right)$ & 0.02 & 0.02 & 0.02 \\
$\mathrm{~N}^{-\mathrm{NO}_{3}}-\left(\mathrm{mg} \mathrm{l}^{-1}\right)$ & 7.1 & 9.7 & 10.5 \\
$\mathrm{SRP}\left(\mathrm{mg} \mathrm{l}^{-1}\right)$ & 0.05 & 0.07 & 0.06 \\
$\mathrm{Chl} \mathrm{a}\left(\mathrm{\mu g} \mathrm{l}^{-1}\right)$ & 22.4 & 34.8 & 41.2 \\
$\mathrm{TSS}\left(\mathrm{mg} \mathrm{l}^{-1}\right)$ & 187 & 293 & 447 \\
\hline
\end{tabular}

It is well known that oxygen is consumed during decomposition of organic materials in waters and regain of the consumed oxygen is rather slow in surface waters (Reynolds and Descy, 1996), which a fact is naturally affecting organisms living here.

The CCA ordination showed the importance of different environmental variables in determination of both dominant planktonic and epilithic algal species. At the phytoplankton, the first two CCA axis had eigenvalues of 0.89 and 0.84 respectively. The first axis of the CCA explained $15.37 \%$ of the total variance in the phytoplankton taxa. The position of dominant species Pediastrum spp. and Euglena spp. were placed closed to chlorophyll and temperature, Cyclotella meneghiniana was placed closed to SRP, Cymatopleura spp. and Fragilaria spp. were closed to dissolved oxygen vector and Melosira varians was placed near to $\mathrm{pH}$ vector in the ordination diagram of CCA (Figure 4).

At the epilithic algae, the first two CCA axis had eigenvalues of 0.92 and 0.88 respectively. The first axis of the CCA explained $12.21 \%$ of the total variance in the epilithic taxa. The position of dominant species Cymatopleura spp. and Fragilaria spp. were closed to Dissolved oxygen, chlorophyll and $\mathrm{pH}$, Cyclotella meneghiniana was placed closed to Tempreture, Pinnularia spp. and Amphora ovalis were placed closed to temperature and SRP vector in the ordination diagram of CCA (Figure 5).

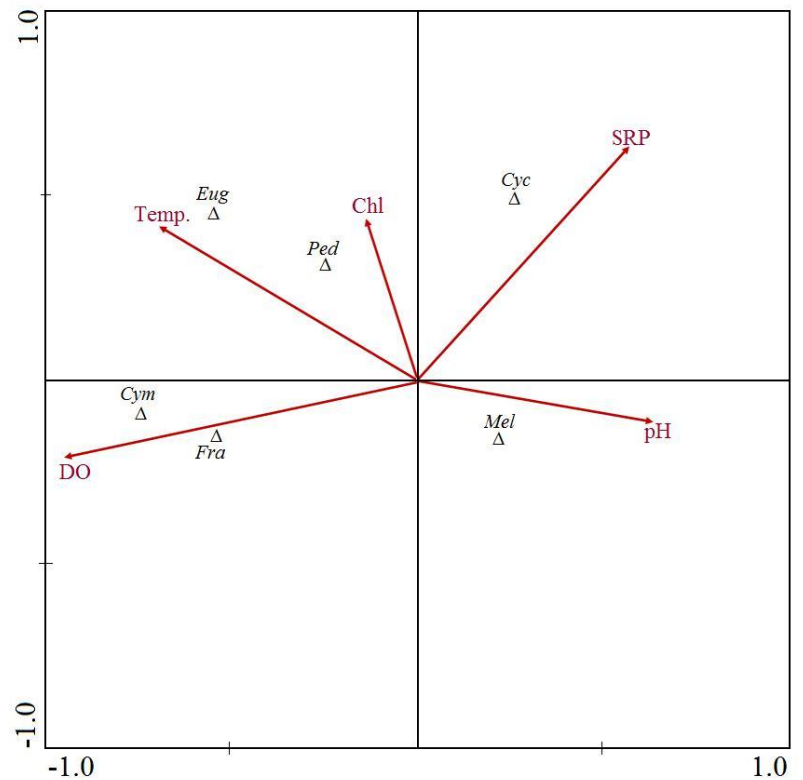

Figure 4. Biplot of first and second CCA axis for phytoplankton in Arda River. Environmental variables: Ped, Pediastrum spp.; Cym, Cymatopleura spp.; Cyc, Cyclotella meneghiniana; Eug, Euglena spp.; Fra, Fragilaria spp.; Mel, Melosira varians; Temp, Temperature; DO, Dissolved Oxygen; SRP, Soluble Reactive Phosphorus; Chl, Chlorophyll a 


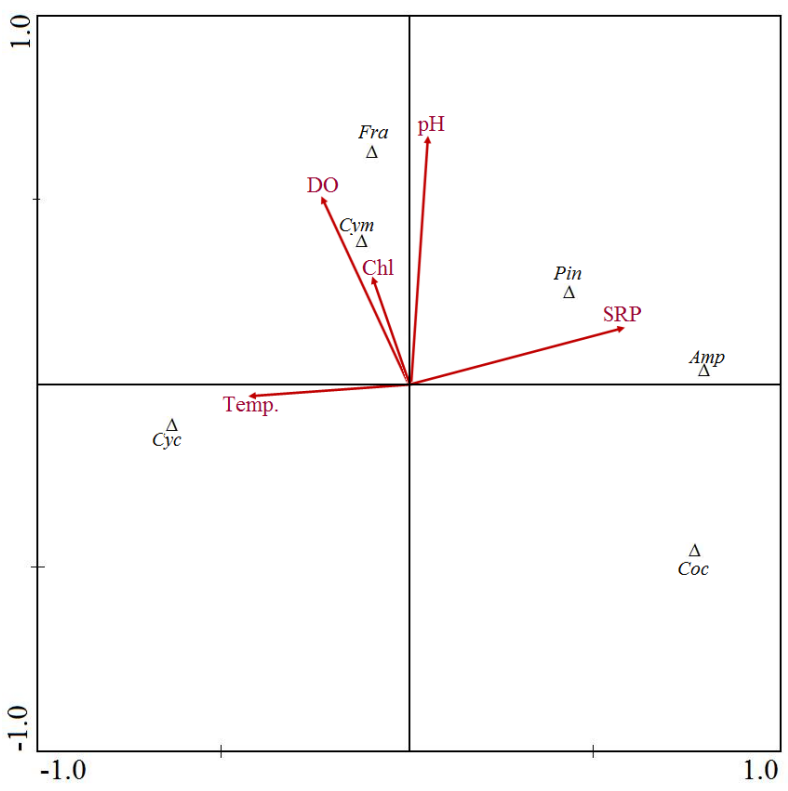

Figure 5. Biplot of first and second CCA axis for epilithic algae in Arda River. Environmental variables: Cym, Cymatopleura spp.; Fra, Fragilaria spp.; Pin, Pinnularia spp.; Amp, Amphora ovalis; Coc, Cocconeis placentula; Temp, Temperature; DO, Dissolved Oxygen; SRP, Soluble Reactive Phosphorus; Chl, Chlorophyll a

In the river, generally the highest biovolume was calculated in July compared to June and May, respectively. On the other hand June has the highest species richness, because the temperature is increasing in the summer and correspondingly evaporation and agricultural irrigation are increasing, the river water level decreased. In contrast, biovolume increases by algae condensation in the plankton. In epilithic algae species there is no obvious change, but the diatoms maintained to increase during summer months; green algae and blue-greens reached to their maximum in June but they declined in July.

In the study conducted by Traykov (2005), blue-greens were determined to be dominant especially in July. In our study Microcystis aeruginosa and Anabaena flosaquae species, probably their source is Kurdzhali Reservoir, was determined in the river plankton.

Except Ergene River, like all other rivers in the MeriçErgene Basin and most of other rivers in our country, Bacillariophyta is the dominant group in Arda River (Öterler et al., 2012, 2014) and Cyclotella meneghiniana is one of the dominant organisms. When water quality of Arda River is compared to the water quality criteria, it is seen that the quality is closer to $1^{\text {st }}$ and $2^{\text {nd }}$ class water quality (YSKYY, 2015). Among the algae determined in the river, species of Euglena, Navicula, Oscillatoria and Fragilaria were determined to have a higher tolerance level against pollution.

Bacillariophyta and Chlorophyta were found to be dominant over other divisios in many studies in other streams of Turkey. From the 62 taxa determined by Aygün (2000) in Seyhan River,
29 belonged to Chlorophyta and 15 belonged to Bacillariophyta. In the study of Soylu and Gönülol (2003), 47 taxa were, of which 31 belonged to Bacillariophyta, 4 belonged to Chlorophyta, reported to constitute Yeşilırmak River phytoplankton. Öterler et al. (2014) stated that 146 taxa constituted Tunca River phytoplankton, 81 of which belonged to Chlorophyta and 45 to Bacillariophyta. Varol and Şen (2014) reported that 390 taxa constituted Dicle River phytoplankton, 153 of which belonged to Bacillariophyta and 125 to Chlorophyta.

Although the planktonic species of Pediastrum, Cyclotella, Cymatopleura, Fragilaria, Melosira, Pinnularia, Euglena, Navicula and Diatoma were determined with high biovolume values in the river during the study periods, Tabellaria fenestrata, Navicula capitata and Nitzschia palea, although were abundant, were recorded with low biovolume values as a result of their small sizes. The epilithic Cymatopleura, Fragilaria, Pinnularia, Cocconeis, Amphora, Cyclotella, Gomphonema and Cymbella were also determined in high numbers during the study period.

Pediastrum spp. (Pediastrum boryanum, Pediastrum duplex and Monactinus simplex) belonging to Chlorophyta were dominant organisms of the plankton in this study. Pediastrum species were reported to be more common in eutrophic waters than in oligotrophic waters (Hutchinson, 1967). On the other hand, these species are characteristic of mesotrophic lakes. The common presence of Pediastrum species and Monactinus simplex in our study area can be a result of presence of these taxa in the 4 dam lakes built along the river. In addition to the dominant presence of Cyclotella species in Arda River in terms of abundance and biovolume, it is known that in general they cause the blooms in river phytoplankton. (Descy et al., 1994; Mitrovic et al., 2008). Cymatopleura are generally benthic and many such species were found in the phytoplankton of Arda River. Mooney (1989) stated that Cymatopleura in particular is strongly benthic forms and that it is difficult to find them in phytoplankton due to their weight. However, it is normal to find benthic species also in phytoplankton due to river currents.

In conclusion, Pediastrum spp. (21.31\%), Cyclotella meneghiniana (12.55\%) and Cymatopleura spp were the dominant taxa in phytoplankton and Cymatopleura spp. (13.84\%), Fragilaria spp. (13.62\%) and Pinnularia spp. $(11.08 \%)$ were the dominant taxa in benthic of Arda River. Relationship between light and nutrients is also important for the growth of algae. Due to high transparency and bed of width in the Arda River, light did not limit the growth of photoautotrophs throughout the water column and river bed. In addition to, water temperature was the determinant for the summer months' variation of environmental and biological parameters. CCA indicated that planktonic species were good relationship physical, chemical, and biological parameters as a result of the summer periods. The algae flora of one of the largest rivers in Meriç-Ergene Basin was determined and the results are thought to contribute to determination of flora of the basin as a whole. 


\section{REFERENCES}

Addinsoft. (2015). XLSTAT, Data analysis and statistics with MS Excel. Addinsoft, NY, USA. xlstat available at http:// www.xlstat.com/en/home.

Algın, Y. (2013). Meriç River early warning system (in Turkish). III. National Flood Symposium. 29-30 April 2013, İstanbul, Turkey.

APHA. 2012. Standard Methods for examination of water and wastewater. 22 ed. Washington: American Public Health Association; APHA, AWWA WEF,1360 pp.

Aygün, Ş. (2000). Physical, chemical and criteria of plankton quality and seasonal changes in which part of inner lake of the Seyhan River (PhD Thesis), (in Turkish with English abstract). Çukurova University Institute of Science, Adana, pp84.

Belkinova, D., Mladenov, R., Dimitrova-Dyulgerova, I., Cheshmedjiev, S. \& Angelova I. (2007). Phytoplankton research in Kurdzhali Reservoir Phytologia Balcanica, 13, 47-52.

Cleve-Euler, A. (1952). Die diatomen von schweden und finnland Stockholm Almquist und Wiksells Bactryckeri Ab. P. Stockholm, 1-153.

Descy, J.-P., Reynolds, C.S. \& Padisak, J. (1994). Phytoplankton in turbid environments. rivers and shallow lakes. Developments in Hydrobiology, Vol. 100. Kluwer Academic Publishers, Dordrecht, Boston, London, 214.

EC (European Communities). (2007). "European Communities (drinking water) (no. 2)", Regulations 2007, S.I. No. 278 of 2007.

Guiry, M.D., Rindi, F. \& Guiry, G.M. (2010). AlgaeBase. World-wide electronic publication, National University of Ireland, Galway. www.algaebase.org.

Hillebrand, H., Dürselen, C., Kirschtel, D., Pollingher, U. \& Zohary T. (1999). Biovolume calculation for pelagic and benthic microalgae. Journal of Phycology, 35, 403-424. doi: 10.1046/j.1529-8817.1999.3520403.x

Husted, F. (1930). Bacillariophyta ( Diyatomeee ) Heft: 10 in a Pascher Die Susswasser Flora Mitteleuropas. Gustav Fischer Published, Jena, Germany, 1-466.

Hutchinson, G.E. (1967). A treatise on limnology, v. 2. Introduction to lake biology and the limnoplankton. Wiley, New York, US, 1048p.

Komarek, J. \& Fott, B. (1983). Die binnnengewässer. Band 26, Das phytoplankton des süßwassers. 7 Teil, 1. Hälfte, Chlorophyceae (Grünalgen), Ordnung: Chlorococcales. E. Schweizerbart'sche Verlagsbuchhandlung, Stuttgart,1-1044.

Krammer, K. \& Lange-Bertalot H. (1991a) Süßwasserflora von Mitteleuropa. Bacillariophyceae, Band 2/3, 3. Teil: Centrales, Fragillariaceae, Eunoticeae. Stuttgart: Gustav Fischer Verlag, 1-576.

Krammer, K. \& Lange-Bertalot H. (1991b) Süßwasserflora von Mitteleuropa. Bacillariophyceae, Band 2/4, 4. Teil: Achnanthaceae. Kritische Ergänzungen zu Navicula (Lineolatae) und Gomphonema Gesamtliteraturverzeichnis. Stuttgart: Gustav Fischer Verlag, 1-436.

Krammer, K. \& Lange-Bertalot, H. (1999). Süßwasserflora von Mitteleuropa. Bacillariophyceae, Band 2/2, 2. Teil: Bacillariaceae, Epithemiaceae, Surirellaceae. Berlin: Spectrum Academicher Verlag, 1- 610.

Mitrovic, S., Chessman, B., Davie, A.W., Avery, E.L. \& Ryan, N. (2008) Development of blooms of Cyclotella meneghiniana and Nitzschia spp. (Bacillariophyceae) in a shallow river and estimation of effective suppression flows. Hydrobiologia, 596, 1, 173-185. doi: $10.1007 /$ s10750-007-9094-1

Mooney, E.P. (1989). A study of Lough Corrib, western Ireland and its phytoplankton. Hydrobiologia, 175: 195-212. doi: 10.1007/BF00006090
Nusch, E. (1980). Comparison of different methods for chlorophyll and phaeopigment determination. Archiv für Hydrobiologie-Beiheft Ergebnisse der Limnologie, 14, 14-36.

Öterler B., Taş, M. \& Kırgız, T., (2012). Seasonal variations of water quality parameters and algal flora of Sazlidere Stream (Edirne) (in Turkish with English abstract). Research Journal of Biological Sciences, 5 (1): 49-55.

Öterler, B., Kırgız, T. \& Albay, M. (2014). Seasonal variations of water quality parameters and algal flora of Tundzha (Tunca) River (Edirne, Turkey). Journal of Ecology, 4, 807-819. doi: 10.4236.oje.2014.413069

Patrick, R. \& Reimer, C.W. (1966). The diatoms of the United States, v. 1. Academy of Natural Sciences. AND. 1975. The diatoms of the United States, v. 2. Academy of Natural Sciences.

Pestalozzi, H.G. (1982). Das phytoplankton des susswasser Teil: 8 E. Schweizerbart'sche Verlagsbuchhandlund ( Nagele U. Obermiller ). Stuttgart, 1-539.

Prescott, G. W. (1973). Algae of Western Great Lake Area. Fifth printing. WMC. Brown Comp. Pub. Dubaque, lowa, 1-977.

Reynolds, C.S. (1996). Algae. In Petts, G. \& Calow, P. [Eds.] River Biota. Diversity and Dynamics. Blackwell Science, Oxford, pp. 6-26.

Reynolds, C.S. \& Descy, J.P. (1996). The production, biomass and structure of phytoplankton in large rivers. Archiv für Hydrobiologie, 10, 161-187. doi: $10.1127 / / r / 10 / 1996 / 161$

Round, F.E. (1953). An investigation of two benthic algal communities in Malharm Tarn. Yorkshire. J Ecol 41, 97-174. doi: 10.2307/2257108

Soylu, E.N. \& Gönülol, A. (2003). Phytoplankton and seasonal variations of the River Yeşilırmak, Amasya, Turkey. Turkish Journal of Fisheries and Aquatic Sciences, 3, 17-24.

Sun, J. \& Liu, D. (2003). Geometric models for calculating cell biovolume and surface area for phytoplankton. Journal of Plankton Research 25, 1331 1346. doi: 10.1093/plankt/fbg096

ter Braak, C.J.F. (1986). Canonical correspondence analysis: a new eigenvector technique for multivariate direct gradient analysis. Ecology 67 (6):1167-79. doi: $10.2307 / 1938672$

Traykov, I. (2005). Factors influencing the trophic state of Kurdzhali Reservoir. PhD Thesis. Sofia University "St. Kliment Ohridski", Sofia, 188pp.

Tolotti, M. (2001). Phytoplankton and littoral epilithic diatoms in high mountain lakes of the Adamello-Brenta Regional Park (Trentino, Italy) and their relation to trophic status and acidification risk. Journal of Limnology, 60:2, 171-188.doi:10.4081/jimnol.2001.1.171.

TS, 266. (2005). Water-water intended for human consumption (In Turkish). Turkish Institute of Standards, Türk Standartları Enstitüsü, ICS 13.060.20.

Utermöhl, H. (1958). Zur Vervollkommung der quantitativen phytoplanktonmethodik. Mitteilungen Internationale Vereinigung für Theoretische und Angewandte Limnologie, 9, 1-38.

Wehr, J.D. \& Descy, J.P. (1998). Use of phytoplankton in large river management. Journal of Phycologia, 34, 741-749.

Wehr, J.D. \& Sheath, R.G. (2003). Freshwater Algae of North America: Ecology and Classification. Academic Press, USA, 935 pp.

Varol, M. \& Şen, B. (2014). Flora of the planktonic algae of the Tigris River (in Turkish with English abstract). Journal of FisheriesSciences.com, 8(4): 252-264. doi:10.3153/jscom.201431

YSKYY. (2015). Surface Water Quality Management Framework (In Turkish). Official Journal of the publication: Date 15.04.2015, No. 29327 